\title{
The Effectiveness of Predict-Explain-Observe-Discuss-Explain (PEODE) Based Laboratory Work Activities on Pre-Service Science Teachers' Science Process Skills
}

\author{
Fatma Coştu ${ }^{\otimes_{1}}$ \& Hale Bayram¹ \\ I Science Education Department, Marmara University, Istanbul, Turkey \\ $\triangle$ fatmacostu@gmail.com
}

\begin{abstract}
This research aims at investigating the effectiveness of the Predict-Explain-ObserveDiscuss-Explain (PEODE) based laboratory work activities on pre-service science teachers' science process skills. A quasi-experimental research model with pre- and post- test via control group was employed in the research. The semi-experimental study was based on 46 preservice science teachers enrolled in the primary Science Education Program a state university. In the research, randomly selected two groups were used, one experimental group $(E G ; n=22)$ and one control group (CG; $n=24)$. While the control group participated in traditional laboratory activities work, the experimental group took part in the PEODE-based laboratory work activities. Laboratory activities were carried out in both groups for a total of 9 weeks, two hours a week. Science process skills test (SPST) measuring five different scientific process skills were presented to them as pre- and post-test in order to assess pre-service science teachers' science process skills. The test scores were analyzed quantitatively with a statistical analysis program. At the end of the research, while there was no significant differences total score of the SPST, significant statistical differences were found between the experimental and control groups in "Making Operational Comments" and "Designing the Research" sub-skills.
\end{abstract}

Keywords: Primary Education, Science Education, Predict-Explain-Observe-Discuss-Explain (PEODE), Science Laboratory, Scientific Process Skills

How to Cite: Coştu, F. \& Bayram, H. (2021). The effectiveness of Predict-Explain-Observe-Discuss-Explain (PEODE) Based Laboratory Works Activities on Pre-Service Science Teachers' Science Process Skills. Mimbar Sekolah Dasar, 8(1), 21-40. doi: http://dx.doi.org/10.53400/mimbar-sd.v8il.30897.

INTRODUCTION Science laboratories are an indispensable learning environment for students to understand science concepts by connecting between "the knowledge they have learned in schools" and "their own experiences". In addition, they are also essential to acquire scientific process skills that enable students to solve complex problems (Hofstein \& Lunetta, 1982; Hofstein \& Lunetta, 2004; Seven \& Engin, 2018; Wolf \& Fraser, 2008). Despite the issue about the importance of science laboratories, science laboratories could not be used effectively in schools due to limited facilities of the schools, their physical deficiencies, and disadvantages of traditional laboratory experiments (Ayas, Çepni, \& Akdeniz 1994-a, b; Coştu et al., 2005; Koretsky, Kelly \& Gummer, 2011; Seven \& Engin, 2018). Based on the results in the related studies on science laboratory, an effective alternative approach to the traditional one, namely "cook-book type", has been introduced and discussed in the literature (e.g. Boyd-Kimball, \& Miller, 2018; Brownell et al., 2012; Nicolaidou et al., 2019). Several of the alternative approaches comprise research-based (Brownell et al., 2012), inquiry-based (Şeşen 
Fatma Coştu and Hale Bayram, The Effectiveness of the Predict-Explain-Observe-Discuss-Explain...

\& Tarhan, 2013), project-based (Tsaparlis \& Gorezi, 2005), constructivist-based (Shiland, 1999), argumentation-based (Karaer, Karademir \& Tezel, 2019), POE (Prediction-ObservationExplanation) based (Bilen, Köse, \& Uşak, 2011; Bilen \& Aydoğdu, 2012) laboratory approach and so on. POE-based laboratory, as one of these approaches, has been used frequently in the literature for the last decade (Barut, 2020; Bilen \& Aydoğdu, 2012; Haglund et al., 2015; Sarl, 2017). The POE has recently been modified as enriched with discussions, and it has been used in many studies (e.g. Coştu, Ayas, \& Niaz, 2012; Coştu \& Karataş, 2015; Samsudin et al., 2017). The POE enriched with discussions was first introduced to the literature as PDEODE (Prediction-Discussion-Explanation-Observation-Discussion-Explanation), supported by discussions before and after the "Observation (O)" phase of the POE. It has been used to promote conceptual change (Asyhari \& Hariyanti, 2020; Coştu et al., 2010; 2012; Demircioğlu, 2017), but not utilized enough to enhance laboratory works.

As the aforementioned explanations, the PDEODE that is enriched by POE with discussions could be utilized to make laboratory works more effective due to gathering positive points of the POE and the argumentation (Coştu et al., 2012). This method was enriched by making discussions before and after the observation phase in the POE. Although the method is considered effective in teaching in the literature, it may be problematic for students to have discussions before the observation (O) phase because the students may catch some clues or the teachers may give clues about the experimental results. Therefore, it is more proper to eliminate the discussion phase before the observation from PDEODE. As a new contribution to science education, the authors utilized the PEODE method instead of PDEODE in order to enhance laboratory works.

According to the rationale of the study, this research aims at investigating the effectiveness of the PEODE-based laboratory works on pre-service science teachers' science process skills. For this purpose, the main problem of the research is; "What is the effect of the PEODE-based laboratory works on pre-service science teachers' scientific process skills?". In addition to this main problem, the research seeks to answer the following sub-problems.

1. Is there a significant difference between pre- and post- scientific process skills test (SPST) scores in both the experimental and control groups?

2. Is there a significant difference between the "Defining Variables" sub-category of the pre- and post- SPST in both the experimental and control groups?

3. Is there a significant difference between the "Making and Defining Hypothesis" subcategory of the pre- and post- SPST in both the experimental and control groups?

4. Is there a significant difference between the "Making Operational Explanations" subcategory of the pre- and post- SPST in both the experimental and control groups? 
5. Is there a significant difference between the "Designing the Research" sub-category of the pre- and post- SPST in both the experimental and control groups?

6. Is there a significant difference between the "Graph and Data Interpretation" subcategory of the pre- and post- SPST in both the experimental and control groups?

\section{THEORETICAL FRAMEWORK}

The POE enriched with discussions was first introduced to the literature as PDEODE. This method has been commonly used in the science education literature. In the research, the PEODE method was used instead of the PDEODE in order to enhance laboratory works. As a theoretical framework, the PEODE method was initially introduced, and then the scientific process skills and related studies were given a critical way.

The PEODE method comprised five steps. In the first step (P: Prediction), an experiment is presented by asking the students to make a prediction individually as to what will happen as a result of the experiment. In the second step (E: Explain), the students justify their predictions via reasoning. In the third step (O: Observe), the students work in their groups to experiment, and individually write their observations of what would happen. In this step, the students also observe changes in the experiment, and the instructor guides them to focus on observations. In the fourth step (D: Discuss), the students are asked to discuss in their groups and then to reconcile their predictions with the actual observations. Afterwards, they are asked to analyze, evaluate, and review their friends' views. In the last step (E: Explain), the students compare all inconsistencies between observations and predictions. The PEODE-based laboratory works were used to enhance pre-service science teachers' science process skills.

Scientific process skills facilitate learning by activating students in science and providing retention in learning for students with research methods and ways (Çepni et al., 1997). Hence, these skills are intended to be developed in both our country (MONE, 2013; MONE, 2018) and international (The International Study Center [ISC], 2000; 2009) science education programs. It is also possible to see a reflection of the importance of scientific process skills in research papers in science education. Therefore, these skills have been used at various levels. Moreover, strategies, methods, and techniques have been used to allow students to gain them effectively. Focusing on the literature review, a wide variety of researchers has investigated scientific process skills to acquire these skills at various levels. For example, primary school level (Aktamış \& Ergin, 2007; Anagün \& Yaşar, 2009; Aydınlı, 2007; Aydoğdu, 2006; Erdoğan, 2010; Güler, 2010; Hazır ve Türkmen, 2008; Keskinkilıç, 2010; Kula, 2009; Saat, 2004; Şahbaz, 2010; Şenyüz, 2008; Tatar, 2006), secondary school level (Azar, Presley \& Balkaya, 2006; Dori \& Sasson, 2008; Dönmez \& Azizoğlu, 2010; Geban, 1990; Roth \& Roychoudhury, 1993; Temiz, 2007; Temiz \& Tan, 2009; Yang \& Heh, 2007), as a higher level, preservice teachers (Bozdoğan et. al., 2006; Campbell, 1979; Downing \& Filer, 1999; Farsakoğlu 
Fatma Coştu and Hale Bayram, The Effectiveness of the Predict-Explain-Observe-Discuss-Explain...

et al., 2008; Kanlı, 2007; Karslı et al., 2010; Koray et al., 2007; Laçin Şimsek, 2010; Scharmann, 1989; Sinan \& Uşak, 2011), teachers (Campbell, 1979; Karslı et al., 2009; Nicosia et al., 1984) and so on. Based on these studies, this shows that scientific process skills are not acquired at the desired level (Akar, 2007; Aydoğdu, 2006; Hazır, 2006; ISC, 2000; 2009; Temiz, 2001; Temiz \& Tan, 2009). In addition to including these skills in science, they can also be acquired by participating teachers in interactive teaching that are compatible with the science curriculum enabling students to gain these skills. In addition, these skills essentially must be developed in the teachers or pre-service teachers. In order to fulfill these requirements, they must have gained these skills truly before performing the teaching tasks. However, the related studies of teachers and teacher candidates about scientific process skills (Farsakoğlu et al., 2008; Karslı et al., 2009; Karslı et al., 2010; Laçin Şimsek, 2010; Sinan \& Uşak, 2011) showed that the acquisition of their skills was insufficient because they could not develop them at the desired level. In this context, this research, as a new contribution to science education literature, seeks to use the PEODE-based laboratory works to improve the pre-service science teachers' skills.

\section{METHOD}

\section{Research Design}

This research employed a quasi-experimental research model with pre- and post- test via the control group. In the context of the research model firstly, an experimental and a control group were randomly selected. Secondly, SPST was applied to both groups as the pre-test. Thirdly, while the intervention was made to the experimental group, the traditional approach was made to the control group. Lastly, SPST was applied to both groups as post-test (Büyüköztürk, 2011; Karasar, 2012; Robson \& McCartan, 2016). The research procedure is presented in Table 1.

Table 1. The Research Procedure

\begin{tabular}{lclc}
\hline & Pre-test & Intervention & Post-Test \\
\hline Control Group $(n=24)$ & SPST* & Traditional Lab & SPST \\
Experimental Group $(n=22)$ & SPST & PEODE-based Lab & SPST \\
\hline * SPST: Scientific Process Skills Test & &
\end{tabular}

* SPST: Scientific Process Skills Test

\section{Research Sample}

A total of 46 pre-service science teachers enrolled in the 3rd grade of the "Science Education Program" at a state university in Istanbul were selected in this research. The sample was taking courses of "Science Laboratory Practices-2" and "Special Teaching Methods-2". The research was conducted on two groups previously classified by the lecturer who teaches the courses in order to perform teaching activities within the scope of the context. While one of the two groups was randomly designated as the experimental group ( $n=22$ ), the other was designated as the control group $(n=24)$. 


\section{Research Instruments and Procedures}

To perform laboratory activities, the sample was divided into four groups in both the experimental and control groups. There were six pre-service science teachers in all groups (except two groups in the experimental group, where there were five pre-service teachers). The pre-service science teachers participated in laboratory works in groups during the practice hours of the two lessons given above. In the laboratory works, the researchers chose fundamental science concepts that the pre-service science teachers will frequently use in their future teaching life and that a plethora of misconceptions exist and related to daily life events (see Table 2). Laboratory activities in both two groups were carried out within a total of nine weeks (two hours per week) in accordance with the content presented in the Table 2. Each laboratory activities in the experimental groups were presented to the pre-service science teachers in worksheets. A worksheet is written materials consisting of three parts (Coştu, Karataş, \& Ayas, 2003; Demircioğlu \& Atasoy, 2006). In the first part of the worksheet, there were an encouraging questions related to real life events. In the second part, the PEODE-based laboratory experiments (see Table 2) and also prompt questions or subquestions for inquiring theirs views were included. In the third part, the evaluation questions to measure or be aware of how the pre-service science teachers' initial thoughts have changed at the end were included. In the control group, the traditional laboratory activities, namely cook-book type (Prescott \& Anger, 1970), were used. In this approach, an experiment paper consists of "name of experiment", "subject", "inquiry question", "tools and equipment", "procedure", "observation", "results" and "what we learnt?" was presented to the preservice science teachers.

The laboratory activities applied to the experimental and control groups were designed by the authors, but the applications were carried out by the instructor of the courses (except from the authors). The authors and the instructor came together, and the first author interactively gave training to the instructor on how to do laboratory activities and what to pay attention while performing. The instructor is an expert on science education, and he has lots research papers with the inclusion of POE and PDEODE. Therefore, it was believed to have a sound understanding and pedagogy to perform these lab activities.

Table 2. The content of the laboratory activities applied to in both groups

\begin{tabular}{cccc}
\hline Worksheets & Lab Activity & \multicolumn{1}{c}{ Contents of Activity } & Time \\
\hline Evaporation-1 & Lab task-1 & $\begin{array}{r}\text { Factors affecting evaporation; } \\
\bullet \quad \text { temperature }\end{array}$ & \\
& Lab task-2 & $\begin{array}{r}\text { Factors affecting evaporation; } \\
\bullet \quad \text { humidity of the air }\end{array}$ & 2 hours \\
Evaporation-2 & Lab task-1 & $\begin{array}{c}\text { Evaporation in different liquids; } \\
\text { evaporation of alcohol }\end{array}$ & 2 hours \\
\hline
\end{tabular}


Fatma Coştu and Hale Bayram, The Effectiveness of the Predict-Explain-Observe-Discuss-Explain...

\begin{tabular}{|c|c|c|c|}
\hline & $\begin{array}{l}\text { Lab task-2 } \\
\text { Lab task-3 }\end{array}$ & $\begin{array}{l}\text { - evaporation of water } \\
\text { - evaporation of oil } \\
\text { Evaporation in different systems; } \\
\text { - in an opened system } \\
\text { - in a closed system } \\
\text { Heat exchange during evaporation; } \\
\text { - heat transfer and drop of the } \\
\quad \text { temperature }\end{array}$ & \\
\hline Condensation & $\begin{array}{l}\text { Lab task-2 } \\
\text { Lab task-3 }\end{array}$ & $\begin{array}{l}\text { Condensation in closed container; } \\
\text { - two systems: room temperature } \\
\quad \text { and cooled condition } \\
\text { Condensation in opened container; } \\
\text { - two systems: room temperature } \\
\quad \text { and cooled condition } \\
\text { Condensation in opened container; } \\
\text { - two systems: cooled condition } \\
\quad \text { and surrounded cold condition }\end{array}$ & 2 hours \\
\hline Boiling-1 & Lab task-1 & $\begin{array}{l}\text { Boiling water at a temperature below } \\
100^{\circ} \mathrm{C} \\
\text { - reduced external pressure with a } \\
\text { - syringe } \\
\text { Boiling wating water at } 70^{\circ} \mathrm{C} \\
\text { reducing ice cubes } \\
\text { boiling water lower temperature }\end{array}$ & 2 hours \\
\hline Boiling-2 & Lab task-1 & $\begin{array}{l}\text { Boiling water at a temperature above } \\
100^{\circ} \mathrm{C} \\
\text { - increasing external pressure with } \\
\text { a syringe } \\
\text { - boiling water above } 100^{\circ} \mathrm{C}\end{array}$ & 2 hours \\
\hline Dissolution & $\begin{array}{l}\text { Lab task-1 } \\
\text { Lab task-2 }\end{array}$ & $\begin{array}{c}\text { The dissolution of a gas into a liquid; } \\
\text { - } \quad \text { pressure effect (with a syringe) } \\
\text { - temperature effect (heating) }\end{array}$ & 2 hours \\
\hline Gas Pressure & $\begin{array}{l}\text { Lab task-1 } \\
\text { Lab task-2 } \\
\text { Lab task-3 }\end{array}$ & $\begin{array}{l}\text { Gas pressure in a closed beaker } \\
\text { increasing gas pressure with heating } \\
\text { Recognizing atmospheric pressure } \\
\text { rising up colored water in a glass tube } \\
\text { (like Torricelli experiment) } \\
\text { Gas pressure in a beaker } \\
\text { decreasing gas pressure with cooling }\end{array}$ & 2 hours \\
\hline Liquid Pressure & Lab task-1 & $\begin{array}{l}\text { Factors affecting liquid pressure; } \\
\text { observing liquid pressure } \\
\text { increasing liquid pressure by immersing } \\
\text { depth } \\
\text { Factors affecting liquid pressure; } \\
\text { liquid pressure in different liquid (water } \\
\text { and vinegar) }\end{array}$ & 2 hours \\
\hline Raoult's Law & Lab task-1 & $\begin{array}{l}\text { Colligative properties of solutions; } \\
\text { - boiling point elevation \& vapor } \\
\text { pressure lowering } \\
\text { Raoult's Law \& boiling point of a } \\
\text { emulsion (water-olive oil } \\
\text { emulsion) } \\
\text { boiling point of water-olive oil } \\
\text { emulsion }\end{array}$ & 2 hours \\
\hline
\end{tabular}


As stated before, the PEODE-based laboratory activities were presented to pre-service science in worksheets. Each worksheet contains one or more PEODE tasks in it. The PEODE tasks comprised of five steps. In the first step (P: Prediction), the instructor presented an experiment about fundamental science concepts and asked the pre-service science teachers to make a prediction individually as to what would happen. After that, they wrote their predictions in blanks in the worksheet. In the second step (E: Explain), they justified their predictions via reasoning. In the third step (O: Observe), the pre-service science teachers again worked in their groups to experiment, and individually wrote their observations in the worksheet about what would happen. In this step, the students also observed changes in the experiment and the instructor guided them to focus on observations. In the fourth step (D: Discuss), they were asked to discuss in their groups, and then to reconcile their predictions with the actual observations made in the science laboratory. After that, they were asked to analyze, evaluate, and review their friends' works in the other groups. In the last step (E: Explain), they compared all inconsistencies between observations and predictions. The preservice science students in each group were asked to attain a concurrence and consequence about experiment, and to present their ideas to other group members through whole-class debates. The role of the instructor was to challenge students and to enable discussions. Moreover, the instructor asked challenging questions, and did warrant that they did observations carefully.

\section{Data Collection}

To determine the effects of the intervention on the experimental group, the "Scientific Process Skills Test (SPST)" developed by Burns, Okey \& Wise (1985) and adapted to Turkish by Geban, Asskar, \& Özkan (1992) was used to collect the data in this research. The test consisted of 36 multiple choices and Turkish version was conducted to the sample. It also measure different scientific process skills. These skills are given with the question items in Table 3.

Table 3. Distribution of the Questions in the Scientific Process Skills Test

\section{Sub-Scientific Process Skills}

1. Defining Variables

2. Forming and Defining Hypothesis

3. Making Operational Comments

4. Designing the Research

5. Interpreting Graph and Data
Questions in SPST

$1,3,13,14,15,18,19,20,30,31,32,33$
$4,5,8,12,16,17,26,29,36$
$2,7,22,23,24,34$
$10,21,25$
$6,9,11,27,28,35$

The internal consistency reliability coefficient of the original of the SPST was found to be KR-21 $=0.82$ (Okey, Wise, \& Burns, 1985). The reliability coefficient of the test adapted to Turkish language was calculated (Geban, Aşkar, \& Özkan, 1992) and found as 0.81. Also, a pilot research was carried out by applying SPST to 141 pre-service science teachers, and the Cronbach Alpha reliability constant was calculated as 0.729 . The data about reliability coefficients were evaluated as an adequate test in terms of the reliability of SPST. 
Fatma Coştu and Hale Bayram, The Effectiveness of the Predict-Explain-Observe-Discuss-Explain...

\section{Data Analysis}

SPST in both tests was scored by giving "1 point" for correct question and "0 point" for incorrect or left blank question. Subsequently, it was determined whether the scores were distributed according to the normal distribution in order to determine whether the answers given to the test were analyzed with parametric or non-parametric tests. For this purpose, the Shapiro-Wilk Test results were used since the total sample size in the experimental and control groups was less than 50 (Shapiro \& Wilk, 1965; Demir, Saatçioğlu \& Imrol, 2016).

\section{RESULTS}

Each pre-service science teachers' total scores in both pre- and post- SPST test were calculated for both groups in the experimental and control groups. The total results were presented in Table 4.

Table 4. Total scores of pre- and post- SPST in both the experimental and control groups

\begin{tabular}{ccccccc}
\hline $\begin{array}{c}\text { Science Teachers' } \\
\text { Code }\end{array}$ & \multicolumn{3}{c}{ Experimental Group } & \multicolumn{3}{c}{ Control Group } \\
Pre-test & Post-test & Changes & Pre-test & Post-test & Changes \\
\hline S1 & 33 & 34 & +1 & 25 & 32 & +7 \\
S2 & 29 & 31 & +2 & 32 & 32 & 0 \\
S3 & 33 & 35 & +2 & 29 & 34 & +5 \\
S4 & 30 & 33 & +3 & 32 & 32 & 0 \\
S5 & 20 & 30 & +10 & 29 & 30 & +1 \\
S6 & 26 & 33 & +7 & 28 & 33 & +5 \\
S7 & 29 & 34 & +5 & 31 & 31 & 0 \\
S8 & 33 & 36 & +3 & 29 & 33 & +4 \\
S9 & 34 & 34 & 0 & 26 & 26 & 0 \\
S10 & 31 & 33 & +2 & 26 & 28 & +2 \\
S1 & 31 & 34 & +3 & 27 & 31 & +4 \\
S12 & 29 & 33 & +4 & 32 & 32 & 0 \\
S13 & 34 & 35 & +1 & 25 & 32 & +7 \\
S14 & 32 & 35 & +3 & 33 & 34 & +1 \\
S15 & 26 & 34 & +8 & 33 & 33 & 0 \\
S16 & 20 & 28 & +8 & 26 & 26 & 0 \\
S17 & 23 & 30 & +7 & 32 & 35 & +3 \\
S18 & 35 & 36 & +1 & 22 & 24 & +2 \\
S19 & 27 & 32 & +5 & 30 & 30 & 0 \\
S20 & 31 & 34 & +3 & 24 & 32 & +8 \\
S21 & 25 & 34 & +9 & 29 & 29 & 0 \\
S22 & 28 & 31 & +3 & 30 & 30 & 0 \\
S23 & - & - & - & 28 & 29 & +1 \\
S24 & - & - & - & 28 & 30 & +2 \\
\hline Mean & $\mathbf{2 9 . 0 5}$ & $\mathbf{3 3 . 1 4}$ & $\mathbf{+ 4 . 0 9}$ & $\mathbf{2 8 . 5 8}$ & $\mathbf{3 0 . 7 5}$ & $\mathbf{+ 2 . 1 7}$ \\
\hline
\end{tabular}

In order to decide whether analyzed using parametric tests or non-parametric tests, a statistical analysis was used to determine whether the data in Table 4 showed a normal distribution. For this purpose in the research, Shapiro-Wilk Test results were used because the total sample size in each of the experimental and control groups was less than 50 . The total scores pre-tests of the pre-service science teachers in the experimental and control groups 
showed a normal distribution based on the Shapiro-Wilk test results ( $p=.394>.05$ for the control group and $p=.129>.05$ for the experimental group). The pre-service science teachers' in both groups total scores indicated a normal distribution $(p>.05)$ according to the Shapiro-Wilk test results $(p=.118>.05$ for the control group and $p=.058>.05$ for the experimental group). Since the pre-tests scores in both groups showed normal distribution, the results of independent group t-test analysis of the parametric tests were used (see Table 5 and Table 6).

Table 5. Comparison of Pre- SPST Scores of Experimental and Control Groups with Independent Group t-test

\begin{tabular}{|c|c|c|c|c|c|c|}
\hline \multirow{2}{*}{ TEST } & \multirow{2}{*}{ GROUP } & \multirow{2}{*}{$\mathbf{n}$} & \multirow[t]{2}{*}{$\bar{X}$} & \multirow{2}{*}{ sd } & \multicolumn{2}{|c|}{ t-Test } \\
\hline & & & & & $t$ & $p$ \\
\hline \multirow{2}{*}{ Pre-Test } & Control Group & 24 & 28.58 & 3.02 & \multirow{2}{*}{.674} & \multirow{2}{*}{.138} \\
\hline & Experimental Group & 22 & 29.05 & 4.33 & & \\
\hline
\end{tabular}

From Table 5, there was no a significant statistical difference between the pre-SPST scores of the experimental and control groups $(t=0.674, p=0.138>.05)$. This implied that the SPST scores of the experimental and control groups were close to each other before the intervention.

Since the post- SPST of the experimental and control groups showed normal distribution, the results of the independent group t-test analysis of the parametric tests were used.

Table 6. Comparison of Post- SPST Scores of Experimental and Control Groups with Independent Group t-test

\begin{tabular}{|c|c|c|c|c|c|c|}
\hline \multirow{2}{*}{ TEST } & \multirow{2}{*}{ GROUP } & \multirow{2}{*}{$\mathbf{n}$} & \multirow[t]{2}{*}{$\bar{X}$} & \multirow{2}{*}{ sd } & \multicolumn{2}{|c|}{ t-Test } \\
\hline & & & & & $t$ & $\mathbf{p}$ \\
\hline \multirow[t]{2}{*}{ Post-Test } & Control Group & 24 & 30.75 & 2.72 & \multirow{2}{*}{.002} & \multirow{2}{*}{.216} \\
\hline & Experimental Group & 22 & 33.14 & 2.05 & & \\
\hline
\end{tabular}

From Table 6, there was no a significant statistical difference between the post-SPST scores of the experimental and control groups $(t=0.002, p=0.216>.05)$. This result showed that the post-SPST scores of the experimental and control groups were close to each other after the intervention. The result also showed that the intervention in the experimental group (i.e. the PEODE-based laboratory) and the traditional laboratory approach performed in the control group increased pre-service teachers' scientific process skills to a very similar level.

Although there was no significant difference between the total score of SPST, it was statistically analyzed whether there was a significant difference between the pre- and post- 
Fatma Coştu and Hale Bayram, The Effectiveness of the Predict-Explain-Observe-Discuss-Explain...

tests in both groups as regards sub-scientific process skills. Hence, firstly, Shapiro-Wilk Test results were used whether each sub-skills showed normal distribution.

Table 7. Shapiro-Wilk results of the sub-skills of SPST

\begin{tabular}{|c|c|c|c|c|c|}
\hline \multirow{2}{*}{ Sub-Skills } & \multirow{2}{*}{ Test } & \multicolumn{2}{|c|}{ Experimental Group $(n=22)$} & \multicolumn{2}{|c|}{ Control Group ( $n=24)$} \\
\hline & & Statistic & $p$ & Statistic & $p$ \\
\hline \multirow{2}{*}{ Defining Variables } & Pre- & .941 & $.207 b$ & .776 & $.000^{a}$ \\
\hline & Post- & .873 & $.009 a$ & .722 & $.000^{a}$ \\
\hline \multirow{2}{*}{$\begin{array}{l}\text { Forming and Defining } \\
\text { Hypothesis }\end{array}$} & Pre- & .877 & $.011 a$ & .898 & $.020 a$ \\
\hline & Post- & .782 & $.000 a$ & .853 & $.003 a$ \\
\hline \multirow{2}{*}{$\begin{array}{l}\text { Making Operational } \\
\text { Comments }\end{array}$} & Pre- & .867 & $.007 a$ & .872 & $.006^{a}$ \\
\hline & Post- & .875 & $.010 a$ & .693 & $.000 \mathrm{a}$ \\
\hline \multirow{2}{*}{ Designing the Research } & Pre- & .613 & $.000 a$ & .721 & $.000^{a}$ \\
\hline & Post- & .590 & $.000 a$ & .316 & $.000 a^{a}$ \\
\hline \multirow{2}{*}{$\begin{array}{l}\text { Interpreting Graph and } \\
\text { Data }\end{array}$} & Pre- & .768 & $.000 a$ & .828 & $.001 a$ \\
\hline & Post- & .684 & $.000 a$ & .702 & $.000^{a}$ \\
\hline
\end{tabular}

$a:$ Since $p<0.05$ does not show normal distribution

b: Since $p>0.05$ shows normal distribution

From Table 7, all sub-skills (except for the first sub-skill) did not show the normal distribution in both tests and both groups $(p<0.05)$. Therefore, the nonparametric Mann-Whitney-U test was used for statistical comparison (Hollander, Wolfe \& Chicken, 2013). Statistical results are given in Table 8 for the pre-test and in Table 9 for the post-test.

Table 8. Comparison of Pre-test Scores with the Mann-Whitney U Test

\begin{tabular}{|c|c|c|c|c|c|c|}
\hline Sub-Skills & Group & $\mathbf{N}$ & Mean Rank & $\begin{array}{l}\text { Sum of } \\
\text { Ranks }\end{array}$ & U & $\mathbf{p}$ \\
\hline \multirow{2}{*}{ Defining Variables } & Experimental & 22 & 18.70 & 411.50 & \multirow{2}{*}{158.500} & \multirow{2}{*}{$.018^{*}$} \\
\hline & Control & 24 & 27.90 & 669.50 & & \\
\hline \multirow{2}{*}{$\begin{array}{l}\text { Forming and Defining } \\
\text { Hypothesis }\end{array}$} & Experimental & 22 & 27.27 & 600.00 & \multirow{2}{*}{181.000} & \multirow{2}{*}{.053} \\
\hline & Control & 24 & 20.04 & 481.00 & & \\
\hline \multirow{2}{*}{$\begin{array}{l}\text { Making Operational } \\
\text { Comments }\end{array}$} & Experimental & 22 & 22.59 & 497.00 & \multirow{2}{*}{244.000} & \multirow{2}{*}{.645} \\
\hline & Control & 24 & 24.33 & 584.00 & & \\
\hline \multirow{2}{*}{ Designing the Research } & Experimental & 22 & 24.68 & 543.00 & \multirow{2}{*}{238.000} & \multirow{2}{*}{.506} \\
\hline & Control & 24 & 22.42 & 538.00 & & \\
\hline \multirow{2}{*}{$\begin{array}{l}\text { Interpreting Graph and } \\
\text { Data }\end{array}$} & Experimental & 22 & 25.27 & 556.00 & \multirow{2}{*}{225.000} & \multirow{2}{*}{.354} \\
\hline & Control & 24 & 21.88 & 525.00 & & \\
\hline
\end{tabular}

From Table 8, there was no significant difference that was found between the pre-service teachers in the experimental and control groups in all sub-skills except for the "Identifying Variables" ( $p>0.05$ ). In this sub-dimension, a significant difference was found between the pre-service teachers in both groups $(p<0.05)$.

From Table 9, there was no significant difference between the pre-service teachers in the experimental and control groups in all sub-skills ( $p>0.05$ ) except for three sub-skills namely, "Identifying Variables", "Making Operational Comments" and "Designing the Research" sub- 
dimensions. In the three sub-skills, there was a significant difference between the pre-service teachers in the experimental and control groups $(p<0.05)$. These findings showed that the intervention in the experimental group was more effective to enhance these three sub-skills compared to the traditional group.

Table 9. Comparison of Post-test Scores with the Mann-Whitney U Test

\begin{tabular}{|c|c|c|c|c|c|c|}
\hline Sub-Skills & Group & $\mathbf{N}$ & Mean Rank & $\begin{array}{l}\text { Sum of } \\
\text { Ranks }\end{array}$ & U & p \\
\hline \multirow{2}{*}{ Defining Variables } & Experimental & 22 & 19.45 & 428.00 & \multirow{2}{*}{175.000} & \multirow{2}{*}{$.038^{*}$} \\
\hline & Control & 24 & 27.21 & 653.00 & & \\
\hline \multirow{2}{*}{$\begin{array}{l}\text { Forming and Defining } \\
\text { Hypothesis }\end{array}$} & Experimental & 22 & 23.32 & 513.00 & \multirow{2}{*}{260.000} & \multirow{2}{*}{.924} \\
\hline & Control & 24 & 23.67 & 568.00 & & \\
\hline \multirow{2}{*}{$\begin{array}{l}\text { Making Operational } \\
\text { Comments }\end{array}$} & Experimental & 22 & 18.52 & 407.50 & \multirow{2}{*}{154.500} & \multirow{2}{*}{$.010^{*}$} \\
\hline & Control & 24 & 28.06 & 673.50 & & \\
\hline \multirow{2}{*}{ Designing the Research } & Experimental & 22 & 20.68 & 455.00 & \multirow{2}{*}{202.000} & \multirow{2}{*}{$.047^{*}$} \\
\hline & Control & 24 & 26.08 & 626.00 & & \\
\hline \multirow{2}{*}{$\begin{array}{l}\text { Interpreting Graph and } \\
\text { Data }\end{array}$} & Experimental & 22 & 23.86 & 525.00 & \multirow{2}{*}{256.000} & \multirow{2}{*}{.838} \\
\hline & Control & 24 & 23.17 & 556.00 & & \\
\hline
\end{tabular}

From Table 8 and Table 9, in the sub-skills of "Identifying Variables", there were significant differences between the experimental and control groups in both pre- and post-test. To specify the significant differences in these sub-skills, statistical analyzes were made. For this, firstly, the Shapiro-Wilk Test results were taken into consideration, as the differences show normal distribution or not. The obtained data $(p=0.000<0.05$ for the experimental group; $p=$ $0.001<0.05$ for the control group) revealed that it did not show a normal distribution ( $p<$ 0.05). Therefore, pre-test and post- test differences of Identifying Variables' scores were compared via nonparametric statistical tests.

Table 10. Mann-Whitney U Test Results of the Differences in the "Identifying Variables" Sub-Skill

\begin{tabular}{|c|c|c|c|c|c|c|}
\hline TEST & GROUP & $\mathbf{n}$ & Mean Rank & $\begin{array}{l}\text { Sum of } \\
\text { Ranks }\end{array}$ & \multicolumn{2}{|c|}{$\begin{array}{cc}\text { Mann-Whitney U Test } \\
U\end{array}$} \\
\hline \multirow{3}{*}{$\begin{array}{l}\text { Difference } \\
\text { (Pre- and } \\
\text { Post) }\end{array}$} & Control Group & 24 & 23.42 & 562.00 & \multirow{3}{*}{262.000} & \multirow{3}{*}{.963} \\
\hline & & & & & & \\
\hline & Experimental Group & 22 & 23.59 & 519.00 & & \\
\hline
\end{tabular}

From Table 10, there was no significant difference between the pre- and post- tests of the experimental and control groups in the "Identifying Variables" $(U=262,000 p=0.963>0.05)$.

\section{DISCUSSION}

This research sought to investigate the effectiveness of the PEODE-based laboratory works on pre-service science teachers' science process skills. For this purpose, the main problem of the research was; "What is the effect of the PEODE based laboratory activities on pre-service 
Fatma Coştu and Hale Bayram, The Effectiveness of the Predict-Explain-Observe-Discuss-Explain...

science teachers' scientific process skills?" To answer the question, we used a quasiexperimental research model with pre- and post- test via control group. While the control group participated in traditional laboratory work activities, the experimental group took part in the PEODE-based laboratory work activities. Laboratory works activities were carried out in both groups for a total of 18 hours in total 9 weeks, two hours a week. To assess pre-service science teachers' science process skills, a science process skills test (SPST) test including thirtysix multiple-choice test items was presented to them as pre- and post-test.

The data of this research revealed that the PEODE-based laboratory works (the experimental group) positively contributed to the development of pre-service science teachers' scientific process skills compared to the traditional laboratory works (the control group). As known from the literature, science laboratories are one of the most important learning environments in the development of scientific process skills in science (Karsll, 2011). However, even if science laboratory is essential, the related studies have shown that traditional laboratory approaches, which are widely used, do not develop the scientific process skills of students and teacher candidates at the desired level (Aydoğdu, 2006; Farsakoğlu et al., 2008; Hazır \& Türkmen, 2008; Kanlı, 2007; Karsli, 2011; Temiz, 2001; Temiz \& Tan, 2009). Since traditional laboratory works mainly emphasized the implementation of the experiments without satisfactory inquiries about the experiment, they are generally inefficient for the development of students' scientific process skills (Kanll, 2007; Karsl, 2011). Hence, the laboratory works were designed to meet the necessities and inquiry, which enable them to develop the scientific process skills and to provide retention learning (Coştu, 2008; Kanlı, 2007; Karslı, 2011). In this context, the PEODE-based laboratory works could be used in science education as an alternative to the traditional laboratory approach to improve scientific process skills.

The origin of the PEODE-based laboratory works is POE based one, and it also indicated that the POE-based laboratory works also contributed affirmatively to scientific process skills (Bilen \& Aydoğdu 2012; Çakır, Güven, \& Özdemir, 2017; Sarı, 2017; Tokur, 2011). To sum up, it could be expressed that counterpart approaches make positive contributions to the development of scientific process skills similarly. For instance, one type of the enriched discussions with POE, i.e. PDEODE, where there were additions of discussions before and after the observation phase (Coştu, 2008; Coştu et al., 2010; 2012; Demircioğlu, 2017) indicated similar results to another type of the enriched discussion with POE, i.e. PEODE, used in this research. In this respect, the whole POE-based approach made positive contributions to the development of scientific process skills. However, unlike the POE, the alternative method contributed to the fact that pre-service science teachers in the experimental group were inquired and pondered their thoughts by reviewing the different thoughts of the students in the experimental group (Coştu, 2008; Coştu et al, 2010; 2012; Demircioğlu, 2017). 
The second important result revealed that this research was related to the sub-skills of the scientific process skill. At the end of the research, there were significant statistical differences between the experimental and control groups in "Making Operational Comments" and "Designing the Research". This result might stem from the PEODE-based laboratory works that brought their predictions together with the plausible reasons before the experimental activities, and then they discuss in their groups and reconcile their predictions after the observation. It is possible to evaluate that pre-service science teachers made predictions before the experiment and having discussions with other classmates in the groups after the experiment enable them to develop in the two sub-skills.

\section{CONCLUSION}

The research results revealed that the PEODE-based laboratory works contributed more to the development of pre-service science teachers' scientific process skills compared to the traditional laboratory. This finding indicated that there were significant differences between the experimental and control groups in "Making Operational Comments" and "Designing the Research". In other words, the pre-service teachers in the experimental group more enhanced the "Making Operational Comments" and "Designing the Research" sub-skills of scientific process skills compared to the control group. To sum up, the PEODE-based laboratory works activities, evaluated as successful in promoting scientific process skills, should be utilized as an effective way of achieving pre-service science teachers' scientific process skills. Since the PEODE-based laboratory works only added "predict" "explain" and "discuss" steps to the traditional laboratory works, it should be utilized in schools and universities to enhance effective teaching due to ease to adapt to the existing science laboratory.

This research has one major limitation. The development of scientific process skills for preservice teachers in a short time could be difficult. In this research, the experiments in both groups were conducted two hours a week for nine weeks. The development of scientific process skills might be acquired in longer periods. Therefore, future research papers on enhancing scientific process skills may be recommended to use longer time by taking this limitation into account.

\section{ACKNOWLEDGEMENT}

The authors thank the instructor (anonymous) for applying the lab activities.

\section{REFERENCES}

Akar, Ü. (2007). Öğretmen adaylarının bilimsel süreç becerileri ve eleştirel düşünme becerileri düzeyleri arasındaki ilişki [The relationship between student teachers' scientific process skills and critical thinking skills], (Unpublished MA Thesis). Institute of Social Sciences, Afyon Kocatepe University, Afyonkarahisar, Turkey. 
Fatma Coştu and Hale Bayram, The Effectiveness of the Predict-Explain-Observe-Discuss-Explain...

Aktamış, H., \& Ergin, Ö. (2007). Bilimsel süreç becerileri ile bilimsel yaratıclık arasındaki ilişkinin belirlenmesi [Investigating the relationship between science process skills and scientific creativity]. Hacettepe University Journal of Education, 33(33), 11-23.

Anagün, Ş., \& Yaşar, Ş. (2009). IIlköğretim Beşinci Sınıf Fen ve Teknoloji Dersinde Bilimsel Süreç Becerilerinin Geliştirilmesi [Developing scientific process skills at Science and Technology course in fifth grade students]. Ilköğretim Online, 8 (3), 843-865.

Asyhari, A., \& Hariyanti, D. (2020). Pengaruh Pembelajaran Integrative Learning (II) Dan Predict, Discus, Explain, Observe, Discuss (PDEODE) Terhadap Pemahaman Konsep [Influece of Integrative Learning (II) and Predict, Discuss, Explain, Observe, Discuss (PDEODE) on Concept Comprehension]. Khazanah Pendidikan Islam, 2(1), 43-51.

Ayas, A., Akdeniz, A. R., \& Çepni, S. (1994-a). Fen bilimlerinde laboratuvarın yeri ve önemi-ı [The place and importance of the laboratory in science-I]. Çağdaş Eğitim, 19, 21-25.

Ayas, A., Çepni, S., \& Akdeniz, A. R. (1994-b). Fen bilimleri eğitiminde laboratuvarın yeri ve önemi-II [The place and importance of the laboratory in science-II]. Çağdaş Eğitim, 205, 7-11.

Aydınlı, E. (2007). İlköğretim 6, 7 ve 8. Sınıf Öğrencilerinin Bilimsel Süreç Becerilerine Illişkin Performanslarının Değerlendirilmesi [Evaluation of $6^{\text {th }}, 7^{\text {th }}$ and $8^{\text {th }}$ grade students' performances regarding scientific process skills] (Unpublished MA Thesis). Institute of Educational Sciences, Gazi University, Ankara, Turkey.

Aydoğdu, B. (2006). İlköğretim Fen ve Teknoloji Dersinde Bilimsel Süreç Becerilerini Etkileyen Değişkenlerin Belirlenmesi [Identification of variables effecting science process skills in primary science and technology course] (Unpublished MA Thesis). Institute of Educational Sciences, Dokuz Eylul University, Izmir, Turkey.

Azar, A., Presley, A., İ., \& Balkaya, Ö., (2006). Çoklu zekâ kuramına dayalı öğretimin öğrencilerin başarı, tutum, hatırlama ve bilişsel süreç becerilerine etkisi [Effect of multiple intelligence theory based instruction on students' achievement, attitude, retention and process skills]. Hacettepe University Journal of Education, 30, 45-54.

Barut, D.D (2020). Kavram ağlarıyla desteklenmiş TGA etkinliklerinin fen bilgisi öğretmen adaylarının laboratuvar tutumlarına, kaygılarına ve bilimsel süreç becerilerine etkisi [The effect of TGA activities supported by concept networks on laboratory attitudes, anxieties and scientific process skills of pre-service science teacher candidates] (Unpublished MA Thesis). Institute of Educational Sciences, Gazi University, Ankara, Turkey.

Bilen, K., \& Aydoğdu, M. (2012). The effect of a laboratory approach based on predictobservation-explain (POE) strategy on the development of students' science process skills and views about nature of science. Gaziantep Üniversitesi Sosyal Bilimler Dergisi, 11 (1), 4969.

Bilen, K., Köse, S., \& Uşak, M. (2011). The effect of laboratory activities designed based on Predict-Observe-Explain (POE) strategy on pre-service science teachers' understanding of osmosis and diffusion subject. Pamukkale Üniversitesi Sosyal Bilimler Enstitüsü Dergisi, 9, 115-127.

Boyd-Kimball, D., \& Miller, K. R. (2018). From cookbook to research: Redesigning an advanced biochemistry laboratory. Journal of Chemical Education, 95(1), 62-67.

Bozdoğan, A. E., Taşdemir, A., \& Demirbaş, M. (2006). Fen bilgisi öğretiminde işbirlikli öğrenme yönteminin öğrencilerin bilimsel süreç becerilerini geliştirmeye yönelik etkisi [The effect of 
cooperative learning method in science education on improving the students' science process skills]. Inönü University Journal of Education, 7 (11), 23-26.

Brownell, S. E., Kloser, M. J., Fukami, T., \& Shavelson, R. (2012). Undergraduate biology lab courses: Comparing the impact of traditionally based" cookbook" and authentic research-based courses on student lab experiences. Journal of College Science Teaching, 41 (4), 36-45.

Burns, J. C., Okey, J. R., \& Wise, K. C. (1985). Development of an integrated process skill test: TIPS II. Journal of Research in Science Teaching, 22(2), 169-177.

Büyüköztürk, \$. (2011). Deneysel desenler: öntest-sontest kontrol grubu, desen ve veri analizi [Experimental designs: pretest-posttest control group, design and data analysis]. Pegem Akademi, Ankara.

Çakır, N. K., Güven, G., \& Özdemir, O. (2017). TGA stratejisinin genel biyoloji laboratuvar uygulamalarında etkililiğine ilişkin bir araştırma [A study on the efficiency of TGA strategy on general biology laboratory applications]. Abant Izzet Baysal University Journal of Education, 17(4), 2014-2035.

Campbell, R.L., (1979). A comparative study of the effectiveness of process skills instruction on reading comprehension of preservice and inservice elementary teachers. Journal of Research in Science Teaching, 16, 123-127.

Çepni, S., Ayas, A., Johnson, D., \& Turgut, M. F. (1997). Fizik öğretimi [Physics teaching]. Ankara: Council of Higher Education / World Bank National Education Development Project.

Coştu, B. (2008). Learning science through the PDEODE teaching strategy: Helping students make sense of everyday situations. Eurasia Journal of Mathematics, Science and Technology Education, 4(1), 3-9.

Coştu, B., \& Karataş, F. Ö. (2015). Tahmin-Tartış-Açıkla-Gözle-Tartış-Açıkla (TaTGA) yöntemi ve kimya öğretiminde uygulama örnekleri [Prediction-Discuss-Explain-Observe-DiscussExplain (TaTGA) method and its application examples in chemistry teaching]. In Sözbilir, M. Ayas, A. (Editör). Kimya öğretimi [Chemistry teaching] (pp. 345-365) Ankara: Pegem Akademi.

Coştu, B., Ayas, A., \& Niaz, M. (2010). Promoting conceptual change in students' understanding of evaporation. Chemistry Education: Research and Practice, 11 (3), 5-16.

Coştu, B., Ayas, A., \& Niaz, M. (2012). Investigating the effectiveness of a POE-based teaching activity on students' understanding of condensation. Instructional Science, 40(1), 47-67.

Coştu, B., Ayas, A., Çalık, M., Ünal, S., \& Karataş, F. Ö. (2005). Fen öğretmen adaylarının çözelti hazırlama ve laboratuvar malzemelerini kullanma yeterliliklerinin belirlenmesi [Determining preservice science teachers' competences in preparing solutions and in use of laboratory tools]. Hacettepe University Journal of Education, 28(28), 65-72.

Coştu, B., Karataş, F. Ö., \& Ayas, A. (2003). Kavram öğretiminde çalışma yapraklarının kullanilması [Using worksheets in concept teaching]. Pamukkale University Journal of Education, 14(14), 33-48.

Demircioğlu, H. (2017). Effect of PDEODE teaching strategy on Turkish students' conceptual understanding: Particulate nature of matter. Journal of Education and Training Studies, 5(7), 78-90. 
Fatma Coştu and Hale Bayram, The Effectiveness of the Predict-Explain-Observe-Discuss-Explain...

Demir, E , Saatçioğlu, Ö. \& İmrol, F. (2016). Uluslararası dergilerde yayımlanan eğitim araştırmalarının normallik varsayımları açısından incelenmesi [Examination of educational researches published in international journals in terms of normality assumptions]. Current Research in Education, 2(3), 130-148.

Demircioğlu, H., \& Atasoy, \$̧. (2006). Çalışma yapraklarının geliştirilmesine yönelik bir model önerisi [A model proposal for the development of worksheets]. Dokuz Eylul University The Journal of Buca Faculty of Education, 19(1), 71-79.

Dönmez, F. \& Azizoğlu, N. (2010). Investigation of the students' science process skills levels in vocational schools: A case of Balıkesir, Necatibey Eğitim Fakültesi Elektronik Fen ve Matematik Eğitimi Dergisi, 4 (2), 79-109.

Dori Y., J. \& Sasson, I. (2008). Chemical understanding and graphing skills in an honors casebased computerized chemistry laboratory environment: The value of bidirectional visual and textual representations, Journal of Research in Science Teaching , 45(2), 219-250.

Downing, J. E., \& Filer, J. D. (1999). Science process skills and attitudes of preservice elementary teachers. Journal of Elementary Science Education, 11 (2), 57-64.

Erdoğan, M. (2010). Grup ve gösteri deney tekniklerinin öğrencilerin bilimsel süreç becerilerine, başarılarına ve hatırda tutma düzeylerine etkileri [Effect of experiment techniques of group and demonstration to students' scientific process abilittes, achievement and the ability of recalling] (Unpublished Doctoral dissertation). Institute of Educational Sciences, Selçuk University, Konya, Turkey.

Farsakoğlu, Ö., F., Şahin. Ç., Karslı, F., Akpınar, M. \& Ültay, N., (2008). A study on awareness levels on prospective science teachers on science process skills in science education, World Applied Sciences Journal, 4(2), 174-182.

Geban, Ö. (1990). Effects of two different instructional treatments on the students chemistry achievement, science process skills, and attitudes towards chemistry at the high school level, (Unpublished Doctoral dissertation). Institute of Social Sciences, METU University, Ankara, Turkey.

Geban, Ö., Askar, P., \& Özkan, Ï. (1992). Effects of computer simulations and problem-solving approaches on high school students. The Journal of Educational Research, 86(1), 5-10.

Güler, Z. (2010). İlköğretim öğrencilerinin SBS puanları ile ders başarıları, bilimsel süreç becerileri ve mantıksal düşünme yetenekleri arasındaki ilişki [The relationship among elementary students' test scores of level determination exam, course achievements, science processing skills and logical thinking skills]. (Unpublished master's thesis), Institute of Social Sciences, Abant Izzet Baysal University, Bolu, Turkey.

Haglund, J., Jeppsson, F., Hedberg, D., \& Schönborn, K. J. (2015). Thermal cameras in school laboratory activities. Physics Education, 50(4), 424.

Hazır, A. \& Türkmen, L. (2008). İlköğretim 5. sınıf öğrencilerinin bilimsel süreç becerileri düzeyleri [Scientific process skills levels of 5th grade students]. Selçuk Üniversitesi Ahmet Keleşoğlu Eğitim Fakültesi Dergisi, 26, 81-96.

Hazır, A. (2006). Illköğretim 5. sınıf öğrencilerinin bilimsel süreç becerilerini elde edebilme düzeyleri [The fifth grade primary school students' the level of acquisition of science process skils].(Unpublished MA Thesis). Institute of Social Sciences, Afyon Kocatepe University, Afyonkarahisar, Turkey. 
Hofstein, A., \& Lunetta, V. N. (1982). The role of the laboratory in science teaching: Neglected aspects of research. Review of Educational Research, 52(2), 201-217.

Hofstein, A., \& Lunetta, V. N. (2004). The laboratory in science education: Foundations for the twentyfirst century. Science Education, 88(1), 28-54.

Hollander, M., Wolfe, D.A. \& Chicken, E. (2013). Nonparametric statistical methods (Third Edition), New York: Wiley.

Kanlı, U., (2007). 7E modeli merkezli laboratuvar yaklaşımı ile doğrulama laboratuvar yaklaşımlarının öğrencilerin bilimsel süreç becerilerinin gelişimine ve kavramsal başarlarına etkisi [The effects of a laboratory based on the 7E model with verification laboratory approach on students' development of science process skills and conceptual achievement], (Unpublished Doctoral dissertation). Institute of Educational Sciences, Gazi University, Ankara, Turkey.

Karaer, G., Karademir, E. \& Tezel, Ö. (2019). Sınıf öğretmen adaylarının fen laboratuvarında argümantasyon tabanlı öğretime yönelik görüşlerinin incelenmesi [Determination of preservice classroom teachers' opinions towards the argumentation based instruction method in science laboratory]. Eskişehir Osmangazi Üniversitesi Sosyal Bilimler Dergisi, 20, 217-241.

Karasar, N. (2012). Bilimsel araştırma yöntemi [Scientific research method]. Ankara: Nobel Yayıncilik.

Karslı, F. (2011). Fen bilgisi öğretmen adaylarının bilimsel süreç becerilerini geliştirmesinde ve kavramsal değişim sağlamasında zenginleştirilmiş laboratuar rehber materyallerinin etkisi [The effect of enriched laboratory guide materials on improving science process skills and conceptual change of prospective science teachers] . (Unpublished Doctoral dissertation). Institute of Educational Sciences, Karadeniz Teknik University, Trabzon, Turkey.

Karslı, F., Şahin, Ç. \& Ayas, A., (2009). Determining science teachers' ideas about the science process skills: A case study, Procedia-Social and Behavioral Sciences, 1 (1), 890-895.

Karslı, F., Yaman, F. \& Ayas, A., (2010). Prospective chemistry teachers' competency of evaluation of chemical experiments in terms of science process skills, Procedia-Social and Behavioral Sciences, 2(2), 778-781.

Keskinklıç, G. (2010). İlköğretim 7. sınıf fen ve teknoloji dersinde uygulanan yansıtıcı düşünmeye dayalı etkinliklerin bilimsel süreç becerilerinin gelişimine ve başarıya etkisi [The effect of reflective thinking based learning activities in 7th class science and technology lesson on the students' achievements and their scientific process skills] (Unpublished Doctoral dissertation). Institute of Educational Sciences, Selçuk University, Konya, Turkey.

Koray, Ö., Köksal, M. S., Özdemir, M., \& Presley, A. İ. (2007). The effect of creative and critical thinking based laboratory applications on academic achievement and science process skills. Elementary Education Online, 6(3), 377-389.

Koretsky, M. D., Kelly, C., \& Gummer, E. (2011). Fundamental research in engineering education. student learning in industrially situated virtual laboratories. Chemical Engineering Education (CEE), 45(3), 219-228.

Kula, Ş. G. (2009). Araşıırmaya dayalı fen öğrenmenin öğrencilerin bilimsel süreç becerileri, başarıları, kavram öğrenmeleri ve tutumlarına etkisi [The effect of inquiry-based science learning on the students science process skills, achievement, concept learning and 
Fatma Coştu and Hale Bayram, The Effectiveness of the Predict-Explain-Observe-Discuss-Explain...

attitude]. (Unpublished Master thesis). Institute of Educational Sciences, Marmara University, Istanbul, Turkey., İstanbul.

Laçin Şimşek, C. (2010). Sınıf öğretmeni adaylarının fen ve teknoloji ders kitaplarındaki deneyleri bilimsel süreç becerileri açısından analiz edebilme yeterlilikleri [Classroom teacher candidates' sufficiency of analyzing the experiments in primary school science and technology textbooks' in terms of scientific process skills]. Illköğretim Online, 9(2), 433445 .

Ministry of National Education [MoNE]. (2013). İlköğretim kurumları (ilkokullar ve ortaokullar) fen bilimleri dersi $(3,4,5,6,7$ ve 8 . sınıflar) öğretim programı [Elementary education institutions (primary and secondary schools) science curriculum $(3,4,5,6,7$ and 8 grades courses)]. Ankara, Turkey.

Ministry of National Education [MoNE]. (2018). Illköğretim kurumları (ilkokullar ve ortaokullar) fen bilimleri dersi $(3,4,5,6,7$ ve 8 . sınıflar) öğretim programı [Elementary education institutions (primary and secondary schools) science curriculum $(3,4,5,6,7$ and 8 grades courses)]. Ankara, Turkey.

Nicosia, A., M., L., Mineo, S., R., M. \& Valenza, M., A. (1984). The relationship between science process abilities of teachers and science achievement of students: An experimental study, Journal of Research in Science Teaching, 21 (8), 853-858.

Prescott, J. R., \& Anger, C. D. (1970). Removing the "cook book" from freshman physics laboratories. American Journal of Physics, 38(1), 58-64.

Robson, C., \& McCartan, K. (2016). Real world research. John Wiley \& Sons, UK.

Roth, W., M. \& Roychoudhury, A., (1993). The development of science process skills in authentic contexts, Journal of Research in Science Teaching, 30(2), 127-152.

Saat, R., M. (2004). The acquisition of integrated science process skills in a web-based learning environment, Research in Science and Technological Education, 22(1), 23- 40.

Şahbaz, Ö. (2010). Illköğretim 5. sınıf fen ve teknoloji dersinde kullanılan farklı yöntemlerin öğrencilerin bilimsel süreç becerileri, problem çözme becerileri, akademik başarıları ve hatırda tutma üzerindeki etkileri [The effects of different methods on students' science process skills, problem solving skills, academic achievements and retentions in primary school fifth grade science and technology lessons], (Unpublished Doctoral dissertation). Institute of Educatioal Sciences, Dokuz Eylul University, Izmir, Turkey.

Samsudin, A., Suhandi, A., Rusdiana, D., Kaniawati, I., \& Coştu, B. (2017). Promoting Conceptual Understanding on Magnetic Field Concept through Interactive Conceptual Instruction (ICl) with PDEODE* E Tasks. Advanced Science Letters, 23(2), 1205-1209.

Sarı, S. (2017) Tahmin-gözlem-açıklama ile birleştirilmiş örnek olay yönteminin genel kimya laboratuvar deneylerinde kullanımasının fen bilgisi öğretmen adaylarının akademik başarısı ve bilimsel süreç becerilerine etkisinin incelenmesi [Investigation of the impact on academic success and science process skills of science teacher candidates by using case study method combined with predict-observe-explain in general chemistry laboratory experiments], (Unpublished Master thesis). Institute of Natural and Applied Sciences, Giresun University, Giresun, Turkey.

Scharmann, L. C. (1989). Developmental influences of science process skill instruction. Journal of Research in Science Teaching, 26(8), 715-726. 
Şenyüz, G. (2008). 2000 yılı fen bilgisi ve 2005 yılı fen ve teknoloji dersi öğretim programlarında yer alan bilimsel süreç becerileri kazanımlarının tespiti ve karşılaştııılması [Determination and comparison of gaining scientific processing skills which lies in 2000 science and 2005 science and techonology curriculum], (Unpublished Master thesis). Institute of Educational Sciences, Gazi University, Ankara, Turkey.

Şesen, B. A., \& Tarhan, L. (2013). Inquiry-based laboratory activities in electrochemistry: High school students' achievements and attitudes. Research in Science Education, 43(1), 413435.

Seven, Ü. M. A. \& Engin, A. O. (2018). Fen bilimleri eğitiminde laboratuvarın önemi [The importance of the laboratory in science education]. TURAN: Stratejik Arastırmalar Merkezi, 10(38), 256-265. doi:http://dx.doi.org/10.15189/1308-8041.

Shapiro, S. S., \& Wilk, M. B. (1965). An analysis of variance test for normality (Complete samples). Biometrika, 52(3, 4), 591-611.

Shiland, T.W. (1999). Constructivism: The implications for laboratory work. Journal of Chemical Education, 76(1), 107-109.

Sinan, O. \& Uşak, M., (2011). Biyoloji öğretmen adaylarının bilimsel süreç becerilerinin değerlendirilmesi [Evaluating of prospective biology teachers' scientific process skills], Mustafa Kemal Üniversitesi Sosyal Bilimler Enstitüsü Dergisi, 8(15), 333-348.

Tatar, N. (2006). İlköğretim fen eğitiminde araştırmaya dayalı öğrenme yaklaşımının bilimsel süreç becerilerine, akademik başarıya ve tutuma etkisi [The effect of inquiry-based learning approaches in the education of science in primary school on the science process skills, academic achivement and attitude], (Unpublished Doctoral dissertation). Institute of Educational Sciences, Gazi University, Ankara, Turkey.

Temiz, B., K. \& Tan, M., (2009). The abilities of first grade students to identify variables and set hypothesis at high school, Kastamonu Education Journal, 17(1), 195-202.

Temiz, B., K. (2001). Lise 1. sınıf fizik dersi programının öğrencilerin bilimsel süreç becerilerini geliştirmeye uygunluğunun incelenmesi [Investigation of the appropriateness of the 9 th grade physics curriculum on the progression of the students scientific process skills], (Unpublished Master thesis). Institute of Educational Sciences, Gazi University, Ankara, Turkey.

Temiz, B., K. (2007). Fizik öğretiminde öğrencilerin bilimsel süreç becerilerinin ölçülmesi [Assessing science process skills in physics teaching], (Unpublished Doctoral dissertation). Institute of Educational Sciences, Gazi University, Ankara, Turkey.

The International Study Center (2000). TIMSS 1999 International science report. https://timssandpirls.bc.edu/timss 1999i/science_achievement_report.html

The International Study Center (2009). TIMSS 2007 International science report. https://timss.bc.edu/TIMSS2007/sciencereport.html

Tokur, F. (2011). TGA stratejisinin fen bilgisi öğretmen adaylarının bitkilerde büyüme-gelişme konusunu anlamalarına etkisi [The effect of POE strategy on preservice science teachers understanding the subject of growth-development in plants], (Unpublished Master thesis). Institute of Natural and Applied Sciences, Adıyaman University, Adıyaman, Turkey.

Tsaparlis, G., \& Gorezi, M. (2005). A modification of a conventional expository physical chemistry laboratory to accommodate an inquiry/project-based component: Method 
Fatma Coştu and Hale Bayram, The Effectiveness of the Predict-Explain-Observe-Discuss-Explain...

and students' evaluation. Canadian Journal of Math, Science \& Technology Education, 5(1), 111-131.

Wolf, S.J. \& Fraser, B.J. (2008). Learning environment, attitudes and achievement among middle-school science students using inquiry-based laboratory activities. Research in Science Education, 38(3), 321-341.

Yang, K., Y. \& Heh, J., S., (2007). The impact of internet virtual physics laboratory instruction on the achievement in physics, science process skills and computer attitudes of 10th-grade students, Journal of Science Education and Technology, 16(5), 451-461. 